\title{
Enhancement of Photosynthetic Efficiency of C3 Plants
}

\author{
B.A. Sowjanya*, B.D. Narayana and S. Shreyas \\ Department of Genetics and Plant Breeding, University of Agricultural Sciences, \\ Dharwad-580005, India \\ *Corresponding author
}

\begin{abstract}
Keywords
Photosynthetic Efficiency of C3

Plants,

Green revolution

Article Info

Accepted:

07 February 2019

Available Online:

10 March 2019 Carbon-dioxide, methane and other greenhouse gases in atmosphere leads to global warming. Photosynthesis is the single most effective natural regulator of carbon dioxide in the Earth's atmosphere. It is timely to consider what new opportunities exist in the current "omics" era to engineer increases in photosynthesis. Significant enhancement of photosynthesis in several C3 plants like rice, wheat and potato occurs due to insertion of $\mathrm{C} 4$ genes into $\mathrm{C} 3$ plants. It has been suggested that the $\mathrm{C} 4$ pathway evolved from $\mathrm{C} 3$ ancestors as an adaptation to high light intensities, high temperatures, and dryness. The $\mathrm{C} 4$ plants have several important characteristics such as high photosynthetic rates, high growth rates, low rates of water loss and a specialized leaf structure, high yields and water \& nitrogen-use efficiencies, by concentrating $\mathrm{CO}_{2}$ around Rubisco, $\mathrm{C} 4$ plants drastically reduce photorespiration and concentration $\mathrm{Of} \mathrm{CO} 2$ to the vicinity of Rubisco in $\mathrm{C} 4$ plants favours the carboxylation of RuBP over its oxygenation. There are three major strategies to improve the photosynthetic efficiency of $\mathrm{C} 3$ plants, such as Improving the quality and quantity of rubisco, Increasing thermotolerance of Rubisco Activase, Increasing $\mathrm{Co}_{2}$ concentration around Rubisco to enhance catalytic rate of Rubisco and to minimize the photorespiration and Over expression of $\mathrm{C} 4$ genes.
\end{abstract}

\section{A B S T R A C T}

A new "Green revolution" is needed in world agriculture to increase crop yields for food and bioenergy, because gains from conventional breeding method are less than world population growth. Efforts to increase crop productivity must also consider global change.

\section{Introduction}

All people, at all times, have physical and economic access to sufficient, safe and nutritious food to meet their dietary needs and food preferences for an active and healthy life'. However, with a burgeoning population, decreasing arable land, stagnation in agricultural production, the erratic and extreme environmental changes due to global warming along with various biotic and abiotic stresses, it becomes an overwhelming task to ensure complete food and nutrient security. Recent statistics reveal that over 870 million people are chronically undernourished in terms of dietary energy supply (FAO, 2012). It is estimated that global food production must increase $50 \%$ by 2030 and $70 \%-100 \%$ by the year 2050, to feed adequately a global population of around nine billion people 
(Covshoff and Hibberd, 2012; Long, 2012; Zhu et al., 2010a). A new "green revolution" is needed in world agriculture to increase crop yields for food and bioenergy, because gains from conventional breeding method are less than world population growth. Efforts to increase crop productivity must also consider global change. Owing to increases in climate uncertainty, it would be most beneficial if genetic improvements increased yields across a range of environments. Increasing the maximum attainable yield of existing food crops could be part of the solution. It is theoretically possible to increase yield potential by $50 \%$ in some species by raising their photosynthetic capacity [Mitchell et al., 2006, Parry et al., 2011, Hibberd et al., 2008]. If this proved possible in practice, then it would greatly contribute to food security. Increasing photosynthetic capacity raises yield potential. Dramatically increasing yield potential is not trivial because the outcome results from complex interactions between contributing components.

During the Green Revolution, light interception and harvest index were maximised. Extending the growing season is undesirable because management practices are tied to cyclical weather patterns that allow production within specific time frames, and canopy production and architecture are thought to be optimized. Yield potential of C3 crops would be improved by approximately $50 \%$ by increasing the photosynthetic efficiency of $\mathrm{C} 3$ by converting $\mathrm{C} 3$ plants to $\mathrm{C} 4$. This led to the suggestion that converting crops from $\mathrm{C} 3$ to $\mathrm{C} 4$ could mitigate the global food crisis [Reynolds et al., 2011].

\section{Photosynthesis}

Photosynthesis is the most important metabolic process relative to crop productivity because carbohydrates account for more than $85 \%$ of the dry weight in plants. It is the process by which green plants and certain other organisms transform light energy into chemical energy. During photosynthesis in green plants, light energy is captured and used to convert water, carbon dioxide, and minerals into oxygen and energy-rich organic compounds.

\section{Modes of photosynthesis}

C3 pathway

C4 pathway

Crassulacean Acid Metabolism

The C3 pathway of photosynthesis evolved first in autotrophic organisms. However, over geologic time plants evolved several CCMs $\left(\mathrm{Co}_{2}\right.$ concentrating mechanisms) in response to decreases in atmospheric $\mathrm{CO}_{2}$ level. Bicarbonate transport system in cyanobacteria, algae and aquatic plants and the $\mathrm{C} 4$ pathway and CAM in higher plants. The most productive crops, such as corn, sorghum and sugarcane, use the $\mathrm{C} 4$ pathway while most of the important agronomic crops, such as rice, wheat and potato, use the $\mathrm{C} 3$ pathway.

\section{C3 pathway}

Plants that survive solely on $\mathrm{C}_{3}$ fixation $\left(\mathrm{C}_{3}\right.$ plants) tend to thrive in areas where sunlight intensity is moderate, temperatures are moderate, carbon dioxide concentrations are around $200 \mathrm{ppm}$ or higher, and groundwater is plentiful. The $\mathrm{C}_{3}$ plants, originating during Mesozoic and Paleozoic eras, predate the $\mathrm{C}_{4}$ plants and still represent approximately 95\% of Earth's plant biomass. $C_{3}$ plants lose $97 \%$ of the water taken up through their roots to transpiration. ${ }^{[2]}$ Examples include rice and barley.

$\mathrm{C}_{3}$ plants cannot grow in very hot areas because $\mathrm{RuBisCO}$ incorporates more oxygen into RuBP as temperatures increase. This leads to photorespiration (also known as the 
oxidative photosynthetic carbon cycle, or C2 photosynthesis), which leads to a net loss of carbon and nitrogen from the plant and can therefore limit growth. In dry areas, $\mathrm{C}_{3}$ plants shut their stomata to reduce water loss, but this stops $\mathrm{CO}_{2}$ from entering the leaves and therefore reduces the concentration of $\mathrm{CO}_{2}$ in the leaves. This lowers the $\mathrm{CO}_{2}: \mathrm{O}_{2}$ ratio and therefore also increases photorespiration. $\mathrm{C}_{4}$ and CAM plants have adaptations that allow them to survive in hot and dry areas, and they can therefore out-compete $\mathrm{C}_{3}$ plants in these areas. The isotopic signature of $\mathrm{C}_{3}$ plants shows higher degree of ${ }^{13} \mathrm{C}$ depletion than the $\mathrm{C}_{4}$ plants, due to variation in fractionation of carbon isotopes in oxygenic photosynthesis across plant types.

\section{C4 photosynthesis}

$\mathrm{C}_{4}$ fixation is an elaboration of the more common $\mathrm{C}_{3}$ carbon fixation and is believed to have evolved more recently. $\mathrm{C}_{4}$ overcomes the tendency of the enzyme RuBisCO to wastefully fix oxygen rather than carbon dioxide in the process of photorespiration. This is achieved by ensuring that $\mathrm{RuBisCO}$ works in an environment where there is a lot of carbon dioxide and very little oxygen. $\mathrm{CO}_{2}$ is shuttled via malate or aspartate from mesophyll cells to bundle-sheath cells. In these bundle-sheath cells $\mathrm{CO}_{2}$ is released by decarboxylation of the malate. $\mathrm{C} 4$ plants use PEP carboxylase to capture more $\mathrm{CO}_{2}$ in the mesophyll cells. PEP Carboxylase (3 carbons) binds to $\mathrm{CO}_{2}$ to make oxaloacetic acid (OAA). The OAA then makes malate (4 carbons). Malate enters bundle sheath cells and releases the $\mathrm{CO}_{2}$. These additional steps, however, require more energy in the form of ATP. Using this extra energy, $\mathrm{C}_{4}$ plants are able to more efficiently fix carbon in drought, high temperatures, and limitations of nitrogen or $\mathrm{CO}_{2}$. Since the more common $\mathrm{C}_{3}$ pathway does not require this extra energy, it is more efficient in the other conditions.
The $\mathrm{C}_{4}$ plants often possess a characteristic leaf anatomy called kranz anatomy, from the German word for wreath. Their vascular bundles are surrounded by two rings of cells; the inner ring, called bundle sheath cells, contains starch-rich chloroplasts lacking grana, which differ from those in mesophyll cells present as the outer ring. Hence, the chloroplasts are called dimorphic. The primary function of kranz anatomy is to provide a site in which $\mathrm{CO}_{2}$ can be concentrated around RuBisCO, thereby avoiding photorespiration. In order to maintain a significantly higher $\mathrm{CO}_{2}$ concentration in the bundle sheath compared to the mesophyll, the boundary layer of the kranz has a low conductance to $\mathrm{CO}_{2}$, a property that may be enhanced by the presence of suberin. The carbon concentration mechanism in $\mathrm{C}_{4}$ plants distinguishes their isotopic signature from other photosynthetic organisms.

\section{Crassulacean acid metabolism (CAM)}

Crassulacean acid metabolism is a carbon fixation pathway that evolved in some plants as an adaptation to arid conditions. In a plant using full CAM, the stomata in the leaves remain shut during the day to reduce evapotranspiration, but open at night to collect carbon dioxide $\left(\mathrm{CO}_{2}\right)$. The $\mathrm{CO}_{2}$ is stored as the four-carbon acid malate in vacuoles at night, and then in the daytime, the malate is transported to chloroplasts where it is converted back to $\mathrm{CO}_{2}$, which is then used during photosynthesis. The pre-collected $\mathrm{CO}_{2}$ is concentrated around the enzyme $\mathrm{RuBisCO}$, increasing photosynthetic efficiency. CAM is an adaptation for increased efficiency in the use of water, and so is typically found in plants growing in arid conditions.

Minimum energy losses showing the percentage remaining (inside arrows) and percentage losses (at right) from an original $100 \%$ calculated for stage of photosynthetic 
energy transduction from sunlight incident on a leaf to plant biomass. Both $\mathrm{C}_{3}$ and $\mathrm{C}_{4}$ (NADP-malic enzyme type) photosynthesis are presented. Calculations assume a leaf temperature of $30{ }^{\circ} \mathrm{C}$ and an atmospheric $\left[\mathrm{CO}_{2}\right]$ of $387 \mathrm{ppm}$. The theoretical maximal photosynthetic energy conversion efficiency (عc) is $4.6 \%$ for $\mathrm{C}_{3}$ and $6 \%$ for $\mathrm{C}_{4}$ plants. These values are for total full-spectrum solar radiation. If the analysis is limited to photosynthetically active radiation (400-700 $\mathrm{nm}$ ), then these values become $9.4 \%$ for $\mathrm{C} 3$ and $12.3 \%$ for $\mathrm{C} 4$.

\section{$\mathrm{C}_{4}$ plants - agronomically desirable traits}

Higher photosynthetic capacity/high carbon assimilation, higher growth rate \& bio mass production, high nutrient and water use efficiency, biofuel production, other benefits from operating at a lower stomatal conductance might include a greater resistance to gaseous pollutants such as ozone or $\mathrm{SO}_{2}$, reduce the deleterious effects of photorespiration on carbon gain by concentrating $\mathrm{CO}_{2}$, leading to increases in radiation use efficiency and productivity, particularly in tropical climates. Due to less solar energy utilization (Fig. 1) and higher photosynthetic losses (Fig. 2) in C3 plants their is need to manipulate $\mathrm{C} 3$ photosynthetic mechanism by converting it to $\mathrm{C} 4$ photosynthetic mechanism, because $\mathrm{C} 4$ has higher solar energy utilization, less photosynthetic losses along with agronomically desirable traits.

\section{Strategies to convert $\mathbf{C 3}$ to $\mathbf{C 4}$ :}

Improving the quality and quantity of rubisco Increasing thermotolerance of Rubisco Activase

Increasing $\mathrm{CO}_{2}$ concentration around Rubisco to enhance catalytic rate of Rubisco and to minimize the photorespiration.

Overexpression of $\mathrm{C} 4$ genes:
Improving the quality and quantity of Rubisco

Rubisco (Ribulose 1,5-bisphosphate carboxylase/oxygenase) is the most abundant protein on Earth and it is an essential component of the photosynthetic process of fixing $\mathrm{CO}_{2}$ into organic carbon. In $\mathrm{C}_{3}$ plants it is known to have low catalytic activity, so enhancing the Rubisco performance via quality control and/or quantity control is an obvious target for both increasing photosynthetic performance and nitrogen use efficiency (Yamori, 2013). Recently it has been reported that $\mathrm{C}_{4}$-Rubisco small subunit $(R b c S)$ gene was introduced to rice which was derived from sorghum, successfully produced chimeric Rubisco with a greater catalytic turnover rate of Rubisco (kcat) in the transgenic rice (Ishikawa et al., 2011). Whitney, et al., (2011) reported that single residues controlling enzymatic properties of Rubisco have been identified and it was successfully engineered to produce greater Rubisco proteins in Flaveria species from C3 to $\mathrm{C} 4$ catalysis.

\section{Increasing thermotolerance of Rubisco Activase}

Thermotolerance of Rubisco Activase has to be increased to sustain Rubisco Activity under high temperature. The activation state of Rubisco is dependent on the heat sensitive enzyme, Rubisco activase. Kurek, et al., (2007) and Kumar et al., (2009) reported that introduction of a thermostable Rubisco activase into Arabidopsis resulted in increases in plant tolerance to heat stress and photosynthetic performance at high temperature. In addition, the thermal stability of photosynthesis was increased slightly when Rubisco activase of maize was overexpressed in rice [Yamori, et al., 2012]. Thus, manipulating Rubisco activase could be a potential target for stimulation of 
photosynthesis and especially growth at high temperature.

Increasing $\mathrm{CO}_{2}$ concentration around Rubisco to enhance catalytic rate of Rubisco and to minimize the photorespiration

Rubisco catalyses net $\mathrm{CO}_{2}$ assimilation in all photosynthetic organisms. Despite this central role, Rubisco is an inefficient enzyme that limits photosynthetic productivity, particularly in plants with the $\mathrm{C} 3$ photosynthetic pathway. Rubisco has a slow carboxylation rate (kcat c) and a relatively low affinity for $\mathrm{CO}_{2}$, with a $\mathrm{Km}$ for $\mathrm{CO}_{2}$ at ambient $\mathrm{O}_{2}$ (Kc air) close to the $\mathrm{CO}_{2}$ concentration in a $\mathrm{C} 3$ leaf mesophyll cell (Galm_es et al., 2014). Rubisco also catalyses D-ribulose-1,5-bisphosphate (RuBP) oxygenation, resulting in the energetically expensive photorespiratory pathway where previously fixed $\mathrm{CO}_{2}$ is lost (Sharkey, 1988).

These features necessitate a large investment in the enzyme (up to $50 \%$ of leaf soluble protein) to support adequate rates of $\mathrm{CO}_{2}$ assimilation (Parry et al., 2013). Increasing the operating efficiency of Rubisco and reducing photorespiration are important approaches for improving yields in C3 crop plants (Whitney et al., 2011; Parry et al., 2013; Carmo-Silva et al., 2015; Long et al., 2015; Ort et al., 2015). The operating efficiency of Rubisco in $\mathrm{C} 3$ plants could be enhanced by elevating the $\mathrm{CO}_{2}$ concentration in the chloroplast by means of carbon concentrating mechanisms (CCMs).

Possibilities include using components of biochemical CCMs (as in C4 and CAM photosynthesis) and/or the biophysical inorganic carbon accumulation mechanisms from cyanobacteria and eukaryotic algae (von Caemmerer et al., 2012; Price et al., 2013; Meyer et al., 2016).

\section{Overexpression of $\mathrm{C} 4$ genes}

Based on (i) the limited factors of photosynthesis in C3 plants and (ii) high photosynthesis efficiency, high rates of biomass accumulation, and high water and $\mathrm{N}$ use efficiency in $\mathrm{C} 4$ plants, biotechnologists have long been intrigued by the overexpression of different enzymes of the C4 pathway in C3 plants (Edwards et al., 2001; Leegood, 2002; Häusler et al., 2002; von Caemmerer and Furbank, 2003).

Hence, individual or multiple enzymes (PEPC, PPDK, PCK, NADP-ME and NADP-MDH) of the $\mathrm{C} 4$ pathway have been overexpressed in different C3 plants (e.g. tobacco, potato, rice and Arabidopsis).

Ishimaru et al., (1998) overexpressed a C4 maize PPDK gene in $\mathrm{C} 3$ transgenic potato. PPDK activity in the leaves of transgenic potatoes was up to 5.4-fold higher than that of the control plants (WT and treated control plants. A significant increase in the $\delta 13 \mathrm{C}$ value was observed in the transgenic plants, suggesting a certain contribution of PEPC as the initial acceptor of atmospheric $\mathrm{CO}_{2}$.

Their results suggested that elevated PPDK activity may alter carbon metabolism and lead to a partial operation of C4-type carbon metabolism. Zhang et al., (2010) also introduced the intact maize $\mathrm{C} 4-P d k$ gene into rice (Oryza sativa L. indica "IR64").

Expression of C4-Pdk in most transgenic rice lines resulted in the increase of $\mathrm{CO}_{2}$ assimilation rates compared to untransformed control plants.

Lipka et al., (1999) transformed two potato lines using NADP-ME-cDNA constructs. Increased levels of NADP-ME were found in chloroplasts of transformants. 
Fig.1 Solar energy utilization

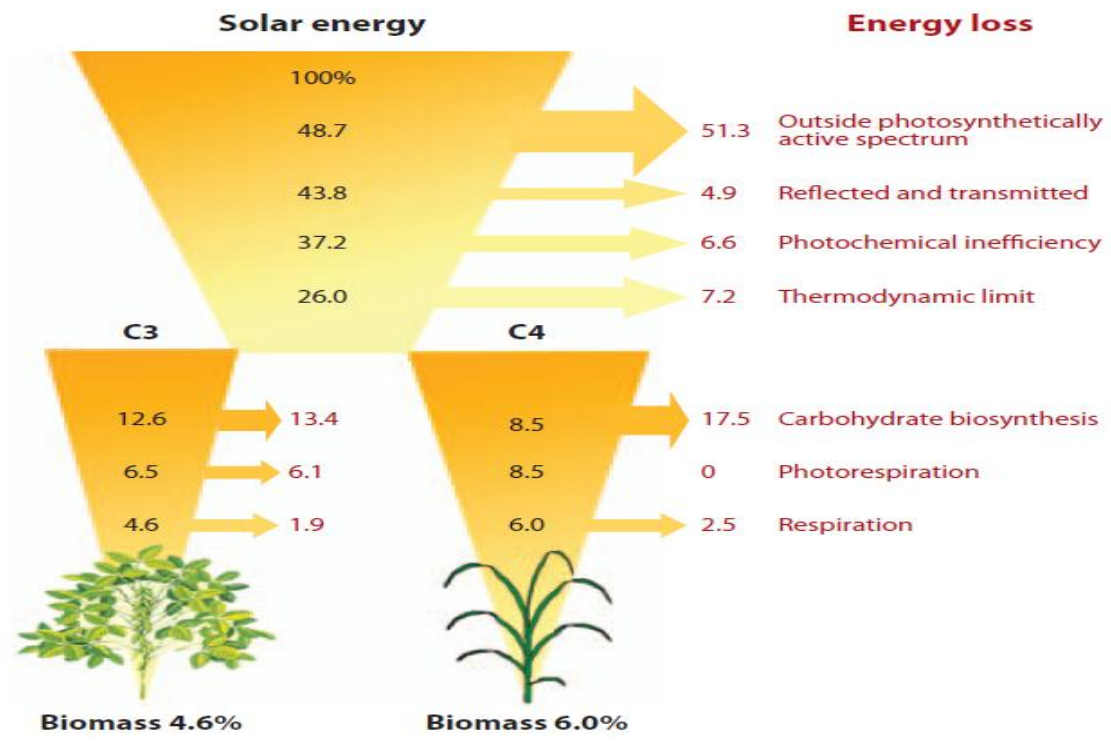

Fig.2 Photosynthetic loses in C3 crop (rice) in the field

\begin{tabular}{|c|c|c|c|c|}
\hline Process & Cause of loss & $\begin{array}{l}\text { Cause and } \\
\text { mechanism }\end{array}$ & $\begin{array}{l}\text { Conditions } \\
\text { under which } \\
\text { loss occurs }\end{array}$ & $\begin{array}{l}\text { Possible remedy for } \\
\text { improvement }\end{array}$ \\
\hline \multirow[t]{3}{*}{ Light harvesting } & Poor absorption & Erect upper leaves & $\begin{array}{l}\text { Large solar } \\
\text { angle at midday }\end{array}$ & $\begin{array}{l}\text { Altered canopy } \\
\text { structure }\end{array}$ \\
\hline & Light saturation & Limitation on $P_{\max }$ & High irradiance & $\begin{array}{l}\text { Improved acclimation } \\
\text { to increase } P_{\max }\end{array}$ \\
\hline & Down-regulation & $\begin{array}{l}\text { Slow relaxation of } \\
\text { non-photochemical } \\
\text { quenching }\end{array}$ & $\begin{array}{l}\text { Fluctuating } \\
\text { light intensity }\end{array}$ & $\begin{array}{l}\text { Decreased and/or } \\
\text { altered } q E\end{array}$ \\
\hline Electron transport & Photoinhibition & $\begin{array}{l}\text { Damage to PSII } \\
\text { reaction centre }\end{array}$ & $\begin{array}{l}\text { Severe stress } \\
\text { conditions, } \\
\text { older leaves? }\end{array}$ & $\begin{array}{l}\text { Improved } \\
\text { photoprotection }\end{array}$ \\
\hline \multirow[t]{3}{*}{$\mathrm{C}$ assimilation } & Photorespiration & Rubisco oxygenase & $\begin{array}{l}\text { High leaf } \\
\text { temperature }\end{array}$ & $\begin{array}{l}\text { Improved Rubisco; } \mathrm{C}_{4} \\
\text { photosynthesis }\end{array}$ \\
\hline & \multirow[t]{2}{*}{ Decline in $P_{\max }$} & $\begin{array}{l}\text { Stomatal } \\
\text { closurefeedback } \\
\text { inhibition }\end{array}$ & $\begin{array}{l}\text { Mid-morning } \\
\text { in high } \\
\text { irradiance }\end{array}$ & $\begin{array}{l}\text { Altered stomatal } \\
\text { responses/carbohydrate } \\
\text { metabolism }\end{array}$ \\
\hline & & Leaf senescence & During grain filling? & $\begin{array}{l}\text { Delayed leaf } \\
\text { senescence }\end{array}$ \\
\hline Partitioning & $\begin{array}{l}\text { Accumulation of } \\
\text { stem carbohydrate }\end{array}$ & $\begin{array}{l}\text { Poor remobilization of } \\
\text { resources }\end{array}$ & During grain filling? & $\begin{array}{l}\text { Altered internal } \\
\text { metabolite signalling }\end{array}$ \\
\hline Respiration & $\begin{array}{l}\text { Loss of fixed } \\
\text { carbon }\end{array}$ & $\begin{array}{l}\text { High } L A I \text { with } \\
\text { inefficient lower } \\
\text { leaves }\end{array}$ & $\begin{array}{l}\text { Mature canopy; } \\
\text { high night }\end{array}$ & $\begin{array}{l}\text { Decreased respiration } \\
\text { capacity; improved } \mathrm{N} \\
\text { economy in lower }\end{array}$ \\
\hline
\end{tabular}


Expression of both genes led to a significantly reduced electron requirement for apparent $\mathrm{CO} 2$ assimilation (e/A) at higher temperature. At low temperatures $\left(15^{\circ} \mathrm{C}\right) 11$ electrons per $\mathrm{CO} 2$ were assimilated (e/A) in controls, single (PEPC or NADP-ME) and double (PEPC and NADP-ME) transformation. However, when the leaf temperature was raised to $36^{\circ} \mathrm{C}$, the electron requirement of the double transformation (15 e/A) was $65 \%$ of controls or single transformation (23 e/A). Thus, the temperature-dependent increase in electron requirement was reduced in the double transformation, suggesting a suppression in the oxygenation reaction of Rubisco.

\section{Challenges associated with placing C4 photosynthesis into $\mathrm{C} 3$ leaves}

The complexity of C4 photosynthesis indicates that its integration into $\mathrm{C} 3$ leaves will be an enormous challenge. Indeed, many domesticated $\mathrm{C} 3$ crops, including rice, belong to genera that are deeply embedded in clades consisting only of C3 species [Sage et al., 2011] and so it can be argued that there is some inherent incompatibility between the current genomes of these species and operation of $\mathrm{C} 4$ photosynthesis. Additionally, major gaps in our knowledge of the $\mathrm{C} 4$ leaf must be addressed. No master regulator(s) has been isolated and loci for many of the transporters associated with metabolite fluxes, modifications to cell biology as well as the specialized anatomy of $\mathrm{C} 4$ leaves remain to be identified. The number of genes essential to a functional $\mathrm{C} 4$ pathway is large. Existing methods of genetic engineering are probably insufficient for its installation, and the engineering challenge will probably increase as we identify more genes essential to $\mathrm{C} 4$.

\section{The compatibility of $\mathrm{C} 3$ leaves with $\mathrm{C} 4$ biochemistry}

Some characteristics of $\mathrm{C} 4$ biochemistry are present in $\mathrm{C} 3$ plants. Cells adjacent to veins in tobacco and Arabidopsis use C4 acid decarboxylases to release $\mathrm{CO} 2$ from malate [Hibberd and Quick, 2008]. Additionally, some endogenous Arabidopsis genes have BS specificity [Brown et al., 2010]. The ability to accumulate enzymes in a cell-specific manner across diverse C3 lineages implies a preexisting regulatory mechanism(s) is recruited during C4 evolution. Consequently, the specific site of enzyme expression and the amount accumulated may only need modification rather than generation de novo when evolving $\mathrm{C} 4$. The latent ability for $\mathrm{C} 3$ genes to be expressed in a $\mathrm{C} 4$ manner was recently demonstrated [Brown et al., 2011].

In conclusion, converting a C3 crop to C4 photosynthesis is an extremely challenging goal to maintain a $\mathrm{C} 4$ plant in a timely manner to alleviate world hunger. To achieve this Grand Challenge consolidated effort by plant biologist of various expertise include physiology, biochemistry, molecular biology and agronomy would be required to achieve the objective of making C3 plant to C4 type, The extent of our understanding of photosynthesis clearly indicates that enough scope is left for improvement and regulation of this ancient and critical biological reaction to achieve our goals of sustainable food production.

\section{References}

Bond, W. J., Woodward, F. I. and Midgley, G. F., 2005, The global distribution of ecosystems in a world without fire. New Phytologist, 165(2): 525-538.

Brautigam, A., Hoffmann-Benning, S. and Weber, A. P., 2008, Comparative proteomics of chloroplast envelopes from $\mathrm{C} 3$ and $\mathrm{C} 4$ plants reveals specific adaptations of the plastid envelope to C4 photosynthesis and candidate proteins required for maintaining $\mathrm{C} 4$ metabolite fluxes. Plant Physiol., 148: 568-579. 
Brautigam, A., Kajala, K., Wullenweber, J., Sommer, M., Gagneul, D., Weber, K. L., Carr, K. M., Gowik, U., Mass, J. and Lercher, M. J., 2011, An mRNA blueprint for $\mathrm{C} 4$ photosynthesis derived from comparative transcriptomics of closely related C3 and C4 species. Plant Physiol., 155:142-156.

Brown, N. J., Palmer, B. G., Stanley, S., Hajaji, H., Janacek, S. H., Astley, H. M., Parsley, K., Kajala, K., Quick, W. P. and Trenkamp, S., 2010, C4 acid decarboxylases required for $\mathrm{C} 4$ photosynthesis are active in the midvein of the C3 species Arabidopsis thaliana, and are important in sugar and amino acid metabolism. Plant J., 61: 122-133.

Brown, N. J., Parsley, K. and Hibberd, J. M., 2005, The future of C4 research -maize, Flaveria or Cleome. Trends Plant Sci., 10: 215-221.

Brown, N. J., Newell, C. A., Stanley, S., Chen, J. E., Perrin, A. J., Kajala, K. and Hibberd, J. M., 2011, Independent and parallel recruitment of preexisting mechanisms underlying C4 photosynthesis. Science, 331: 14361439.

Burnell, J. N. and Chastain, C. J., 2006, Cloning and expression of maize-leaf pyruvate, $\mathrm{Pi}$ dikinase regulatory protein gene. Biochem. Biophys. Res. Commun., 345: 675-680.

Carmo-Silva E, Scales JC, Madgwick PJ, Parry MA. 2015. Optimizing Rubisco and its regulation for greater resource use efficiency. Plant, Cell \& Environment, 38: 1817-1832.

Chastain, C. J., Xu, W. X., Parsley, K., Sarath, G., Hibberd, J. M. and Chollet, R., 2008, The pyruvate, orthophosphate dikinase regulatory proteins of Arabidopsis possess a novel, unprecedented Ser/Thr protein kinase primary structure. Plant J., 53:854-863.
Christin, P. A., Petitpierre, B., Salamin, N., Buchi, L. and Besnard, G., 2009, Evolution of $\mathrm{C} 4$ phosphoenolpyruvate carboxykinase in grasses, from genotype to phenotype. Mol. Biol. Evol., 26: 357-365.

Christin, P. A., Samaritani, E., Petitpierre, B., Salamin, N. and Besnard, G., 2009, Evolutionary insights on $\mathrm{C} 4$ photosynthetic subtypes in grasses from genomics and phylogenetics. Genome Biol. Evol., 1: 221-230.

Christin, P. A., Salamin, N., Savolainen, V., Duvall, M. R. and Besnard, G., 2007, C4 Photosynthesis evolved in grasses via parallel adaptive genetic changes. Curr. Biol., 17: 1241-1247.

Covshoff, S., Majeran, W., Liu P., Kolkman, J. M., van Wijk, K. J. and Brutnell, T. P., 2008, Deregulation of maize C4 photosynthetic development in a mesophyll cell-defective mutant. Plant Physiol., 146: 1469-1481.

Edwards GE, Furbank RT, Hatch MD, Osmond CB. (2001). What does it take to be C4? Lessons from the evolution of C4 photosynthesis. Plant Physiol, 125, 46-49.

Edwards, G., Vonzenesenskaya, E., 2011, C4 photosynthesis: Kranz forms and singlecell $\mathrm{C} 4$ in terrestrial plants. In $\mathrm{C} 4$ Photosynthesis and Related CO2 Concentrating Mechanisms. Kluwer Academic Publishers, 29-60.

Fladung, M., 1994, Genetic variants of Panicum maximum in $\mathrm{C} 4$ photosynthetic traits. J. Plant Physiol, 143: 165-172.

Friso, G., Majeran, W., Huang, M., Sun, Q. and van Wijk, K. J., 2010, Reconstruction of metabolic pathways, protein expression, and homeostasis machineries across maize bundle sheath and mesophyll chloroplasts: large-scale quantitative proteomics using the first maize genome assembly. Plant Physiol., 
152: $1219-1250$.

Furbank, R. T., 2011, Evolution of the C4 photosynthetic mechanism are there really three $\mathrm{C} 4$ acid decarboxylation types. J Exp Bot, 62: 3103-3108.

Galmes J, Kapralov MV, Andralojc PJ, Conesa M_A, Keys AJ, Parry MAJ, Flexas J. 2014. Expanding knowledge of the Rubisco kinetics variability in plant species: environmental and evolutionary trends. Plant, Cell \& Environment 37: 1989-2001.

Gowik, U., Burscheidt, J., Akyildiz, M., Schlue, U., Koczor, M., Streubel, M.and Westhoff, P., 2004, Cis-Regulatory elements for mesophyllspecific gene expression in the $\mathrm{C} 4$ plant Flaveria trinervia, the promoter of the $\mathrm{C} 4$ phosphoenolpyruvate carboxylase gene. Plant Cell, 16: 1077-1090.

Hall, L. N., Roth, R., Brutnell, T. P. and Langdale, J. A., 1998, Cellular differentiation in the maize leaf is disrupted by bundle sheath defective mutations. Symp. Soc. Exp. Biol., 51: 27-31.

Häusler RE, Hirsch HJ, Kreuzaler F, Peterhänsel C. (2002). Overexpression of C4-cycle enzymes in transgenic C3 plants: a biotechnological approach to improve C3-photosynthesis. J Exp Bot, 53, 591-607.

Hatch, M. D., 1987, C4 photosynthesis: a unique blend of modified biochemistry, anatomy and ultrastructure. Biochim Biophys Acta, 895: 81-106.

Herrera, A., 2008, Crassulacean acid metabolism and fitness under water deficit stress: if not for carbon gain, what is facultative CAM good for. Annals of Botany, 103(4): 645-653.

Hibberd, J. M. and Quick, W. P., 2002, Characteristics of $\mathrm{C} 4$ photosynthesis in stems and petioles of C3 flowering plants. Nature, 415: 451-454.

Hibberd, J. M., Sheehy, J. E. and Langdale, J.
A., 2008, Using C4 photosynthesis to increase the yield of rice-rationale and feasibility. Curr Opin Plant Biol, 11: 228-231.

Hibberd, J. M. and Covshoff, S., 2010, The regulation of gene expression required for C4 photosynthesis. Annu. Rev. Plant Biol., 61: 181-207.

Holaday, A. S. and Bowes, G., 1980, C 4 Acid Metabolism and Dark $\mathrm{CO}_{2}$ Fixation in a Submersed Aquatic Macrophyte (Hydrilla verticillata). Plant Physiology 65(2): 331-5.

Ishikawa C, Hatanaka T, Misoo S, Miyake C, Fukayama H., 2011, Functional incorporation of sorghum small subunit increases the catalytic turnover rate of Rubisco in transgenic rice. Plant Physiol, 156: 1603-1611.

Ishimaru K, Ohkawa Y, Ishige T, Tobias DJ, Ohsugi R. (1998). Elevated pyruvate, orthophosphate dikinase (PPDK) activity alters carbon metabolism in $\mathrm{C} 3$ transgenic potato with a $\mathrm{C} 4$ maize PPDK gene. Physiol Plantarum, 103, 340-346.

Kajala, K., Covshoff, S., Karki, S., Woodfield, H., Tolley, B. J., Dionora, M. J., Mogul, R. T., Mabilangan, A. E., Danila, F. R. and Hibberd, J. M., 2001, Strategies for engineering a two-celled $\mathrm{C} 4$ photosynthetic pathway into rice. $J$. Exp. Bot., 62: 3001-3010.

Kolkman, J. M., Conrad, L. J., Farmer, P. R., Hardeman, K., Ahern, K. R., Lewis, P. E., Sawers, R. J., Lebejko, S., Chomet, P. and Brutnell, T. P., 2005, Distribution of Activator (Ac) throughout the maize genome for use in regional mutagenesis. Genetics, 169: 981-995.

Kinoshita, H., Nagasaki, J., Yoshikawa, N., Yamamoto, A., Takito, S., Kawasaki, M., Sugiyama, T., Miyake, H., Weber, A. P. and Taniguchi, M., 2011, The chloroplastic 2-oxoglutarate/malate 
transporter has dual function as the malate valve and in carbon/nitrogen metabolism. Plant J., 65: 15-26.

Kumar A, Li C, Portis Jr AR (2009) Arabidopsis thaliana expressing a thermostable chimeric Rubisco activase exhibts enhanced growth and higher rates of photosynthesis at moderately high temperatures. Photosynth. Res 100: 143-153.

Kurek I, Chang TK, Bertain SM, Madrigal A, Liu L, et al., (2007) Enhanced thermostability of Arabidopsis rubisco activase improves photosynthesis and growth rates under moderate heat stress. Plant Cell 19: 3230-3241.

Leegood RC. (2002). C4 photosynthesis: principles of $\mathrm{CO}_{2}$ concentration and prospects for its introduction into $\mathrm{C} 3$ plants. J Exp Bot, 53, 581-590.

Li, P., Ponnala, L., Gandotra, N., Wang, L., Si, Y., Tausta, S. L., Kebrom, T. H., Provart, N., Patel, R. and Myers, C. R., 2010, The developmental dynamics of the maize leaf transcriptome. Nat Genet, 42: 1060-1067.

Lipka V, Häusler RE, Rademacher T, Li J, Hirsch H-J, Kreuzaler F. (1999). Solanum tuberosum double transgenic expressing phosphoenolpyruvate carboxylase and NADP-malic enzyme display reduced electron requirement for CO2 fixation. Plant Sci, 144, 93105.

Long SP, Marshall-Colon A, Zhu XG. 2015. Meeting the global food demand of the future by engineering crop photosynthesis and yield potential. Cell 161: 56-66.

Majeran, W., Cai, Y., Sun, Q. and van Wijk, K. J., 2005, Functional differentiation of bundle sheath and mesophyll maize chloroplasts determined by comparative proteomics. Plant Cell, 17: 3111-3140.

Majeran, W., Friso, G., Ponnala, L., Connolly, B., Huang, M., Reidel, E.,
Zhang, C., Asakura, Y., Bhuiyan, N. H. and Sun, Q., 2010, Structural and metabolic transitions of $\mathrm{C} 4$ leaf development and differentiation defined by microscopy and quantitative proteomics in maize. Plant Cell, 22: 3509-3542.

Majeran, W. and Van Wijk, K. J., 2009, Celltype-specific differentiation of chloroplasts in $\mathrm{C} 4$ plants. Trends Plant Sci., 14: 100-109.

Majeran, W., Zybailov, B., Ytterberg, A. J., Dunsmore, J., Sun, Q. and van Wijk, K. J., 2008, Consequences of C4 differentiation for chloroplast membrane proteomes in maize mesophyll and bundle sheath cells. Mol. Cell Proteomics, 7: 1609-1638.

Matsuoka, M., Kyozuka, J., Shimamoto, K. and Kano-Murakami, Y., 1994, The promoters of two carboxylases in a $\mathrm{C} 4$ plant (maize) direct cell specific, lightregulated expression in a C3 plant (rice). Plant J., 6: 311-319.

Matsuoka, M. and Numazawa, T., 1991, Cisacting elements in the pyruvate, orthophosphate dikinase gene from maize. Mol. Gen. Genet., 228: 143-152.

Meyer MT, McCormick AJ, Griffiths $\mathrm{H}$. 2016. Will an algal CO2-concentrating mechanism work in higher plants? Current Opinion in Plant Biology 31: 181-188.

Miles, C. D. and Daniel, D. J., 1974, Chloroplast reactions of photosynthetic mutants in Zea mays. Plant Physiol., 53: 589-595.

Miles, C. D., Markwell, J. P. and Thornber, J. P., 1979, Effect of nuclear mutation in maize on photosynthetic activity and content of chlorophyll protein complexes. Plant Physiol., 64: 690-694.

Mitchell, P. L. and Sheehy, J. E., 2006, Supercharging rice photosynthesis to increase yield. New Phytol, 171: 688693. 
Miyao, M., Masumoto, C., Miyazawa, S. and Fukayama, H., 2011, Lessons from engineering a single-cell $\mathrm{C} 4$ photosynthetic pathway into rice. $J$. Exp. Bot., 62: 3021-3029.

Moore, P., 1982, Evolution of photosynthetic pathways in flowering plants. Nature, 295: 647-648.

Nomura, M., Higuchi, T., Ishida, Y., Ohta, S., Komari, T., Imaizumi, N., MiyaoTokutomi, M., Matsuoka, M. and Tajima, S., 2005, Differential expression pattern of $\mathrm{C} 4$ bundle sheath expression genes in rice, a C3 plant. Plant Cell Physiol., 46: 754-761.

Nomura, M., Higuchi, T., Katayama, K., Taniguchi, M., Miyao- Tokutomi, M., Matsuoka, M. and Tajima, S., 2005, The promoter for C4-type mitochondrial aspartate aminotransferase does not direct bundle sheath-specific expression in transgenic rice plants. Plant Cell Physiol, 46: 743-753.

Ort DR, Merchant SS, Alric J, Barkan A, Blankenship RE, Bock R, Croce R, Hanson MR, Hibberd JM, Long SP et al., 2015. Redesigning photosynthesis to sustainably meet global food and bioenergy demand. Proceedings of the National Academy of Sciences, USA 112: 8529-8536.

Osborne, C. P. and Beerling, D. J., 2006, Nature's green revolution: the remarkable evolutionary rise of $\mathrm{C}_{4}$ plants. Philosophical Transactions of the Royal Society B: Biological Sciences, 361(1465): 173-194.

Osborne, C. P. and Freckleton, R. P., 2009, Ecological selection pressures for $\mathrm{C}_{4}$ photosynthesis in the grasses. Proceedings of the Royal Society B: Biological Sciences, 276(1663): 175360.

Parry MA, Andralojc PJ, Scales JC, Salvucci ME, Carmo-Silva AE, Alonso $\mathrm{H}$, Whitney SM. 2013. Rubisco activity and regulation as targets for crop improvement. Journal of Experimental Botany, 64: 717-730.

Parry, M. A., Reynolds, M., Salvucci, M. E., Raines, C., Andralojc, P. J., Zhu, X. G., Price, G. D., Condon, A. G. and Furbank, R. T., 2011, Raising yield potential of wheat. II. Increasing photosynthetic capacity and efficiency. $J$ Exp Bot, 62: 453-467.

Price GD, Pengelly JJ, Forster B, Du J, Whitney SM, von Caemmerer S, Badger MR, Howitt SM, Evans JR. 2013. The cyanobacterial CCM as a source of genes for improving photosynthetic $\mathrm{CO} 2$ fixation in crop species. Journal of Experimental Botany 64: 753-768.

Ranson, S. L. and Thomas, M., 1960, Crassulacean acid metabolism. Annual Review of Plant Physiology, 11 (1): 81110.

Reynolds, M., Bonnett, D., Chapman, S. C., Furbank, R. T., Manes, Y., Mather, D. E. and Parry, M. A., 2011, Raising yield potential of wheat. I. Overview of a consortium approach and breeding strategies. J Exp Bot, 62: 439-452.

Sage, R. F., The evolution of C4 photosynthesis. New Phytol., 161:341370.

Sage, R. F., Christin, P. A. and Edwards, E. J., 2011, The C4 plant lineages of planet Earth. J. Exp. Bot., 62: 3155-3169.

Sharkey TD. 1988. Estimating the rate of photorespiration in leaves. Physiologia Plantarum 73: 147-152.

Stockhaus, J., Schlue, U., Koczor, M., Chitty, J. A., Taylor, W. C. and Westhoff, P., 1997, The promoter of the gene encoding the $\mathrm{C} 4$ form of phosphoenolpyruvate carboxylase directs mesophyll-specific expression in transgenic C4 Flaveria spp. Plant Cell, 9: 479-489.

Taniguchi, Y., Ohkawa, H., Masumoto, C., 
Fukuda, T., Tamai, T., Lee, K., Sudoh, S., Tsuchida, H., Sasaki, H. and Fukayama, H., 2008, Overproduction of C4 photosynthetic enzymes in transgenic rice plants: an approach to introduce the C4-like photosynthetic pathway into rice. J. Exp. Bot., 59: 1799-1809.

Takahashi, H., Watanabe-Takahashi, A., Smith, F. W., Blake-Kalff, M., Hawkesford, M. J. and Saito, K., 2000, The roles of three functional sulphate transporters involved in uptake and translocation of sulphate in Arabidopsis thaliana. Plant J., 23: 171-182.

Von Caemmerer S, Furbank RT. (2003). The C4 pathway: an efficient $\mathrm{CO} 2$ pump. Photosynth Res, 77, 191-207.

von Caemmerer S, Quick WP, Furbank RT. 2012. The development of $\mathrm{C} 4$ rice: current progress and future challenges. Science 336: 1671-1672.

Whitney SM, Sharwood RE, Orr D, White SJ, Alonso H, et al., (2011) Isoleucine 309 acts as a $C 4$ catalytic switch that increases ribulose-1,5-bisphosphate carboxylase/oxygenase

(Rubisco) carboxylation rate in Flaveria. Proc Natl Acad Sci USA 108: 14688-14693.

Wingler, A., Walker, R. P., Chen, Z. H. and Leegood, R. C., 1999, Phosphoenol pyruvate carboxykinase is involved in the decarboxylation of aspartate in the bundle sheath of maize. Plant Physiol, 120:539-546.

Yamori, W., 2013, Improving photosynthesis to increase food and fuel production by biotechnological strategies in crops. Plant Biochemistry \& Physiology, 1(3): 1-3.

Zhu, X. G., Long, S. P. and Ort, D. R., 2010, Improving photosynthetic efficiency for greater yield. Annu Rev Plant Biol, 61: 235-261.

Yamori W, Masumoto C, Fukayama H, Makino A (2012) Rubisco activase is a key regulator of non-steady-state photosynthesis at any leaf temperature and, to a lesser extent, of steady-state photosynthesis at high temperature. Plant J. 71: 871-880.

\section{How to cite this article:}

Sowjanya, B.A., B.D. Narayana and Shreyas, S. 2019. Enhancement of Photosynthetic Efficiency of C3 Plants. Int.J.Curr.Microbiol.App.Sci. 8(03): 775-786.

doi: https://doi.org/10.20546/ijcmas.2019.803.095 